Fanum

Sociológico

\section{Forum Sociológico}

Série II

$24 \mid 2014$

Circulação de saberes e desafios em saúde

\title{
Metodologias qualitativas e quantitativas: de que falamos?
}

Qualitative and quantitative methods: What are we talking about?

\section{Madalena Matos}

\section{(2) OpenEdition \\ Journals}

Edição electrónica

URL: https://journals.openedition.org/sociologico/1061

DOI: 10.4000/sociologico.1061

ISSN: 2182-7427

Editora

CICS.NOVA - Centro Interdisciplinar de Ciências Sociais da Universidade Nova de Lisboa

Refêrencia eletrónica

Madalena Matos, «Metodologias qualitativas e quantitativas: de que falamos?», Forum Sociológico [Online], 24 | 2014, posto online no dia 01 novembro 2014, consultado o 29 março 2022. URL: http:// journals.openedition.org/sociologico/1061 ; DOI: https://doi.org/10.4000/sociologico.1061

Este documento foi criado de forma automática no dia 29 março 2022.

(C) CICS.NOVA 


\title{
Metodologias qualitativas e quantitativas: de que falamos? ${ }^{1}$
}

Qualitative and quantitative methods: What are we talking about?

\author{
Madalena Matos
}

\section{Introdução}

1 Há quase um século que a comunidade científica das ciências sociais discute a oposição entre métodos qualitativos e métodos quantitativos².

2 É assim razoável perguntarmo-nos de que temos falado e de que falamos hoje.

3 Uma pesquisa sobre a documentação armazenada na internet, através do motor Google Scholar, realizada em 8 de outubro de 2012, sucessivamente pelas palavras-chave "qualitative methods" + social, e "quantitative methods" + social permitiu contar o número de documentos onde surgem estas expressões, com a seguinte limitação de períodos de publicação: 1900 a 1920, anos 20, 30, 40, 50, 60, 70, 80, 90 e 2000.

4 Apresentam-se a seguir, na forma de gráficos, os resultados de tais contagens. 0 primeiro gráfico apresenta-nos os períodos entre 1900 e 1980 e o segundo, os períodos entre 1970 e 2010. 
Gráfico 1

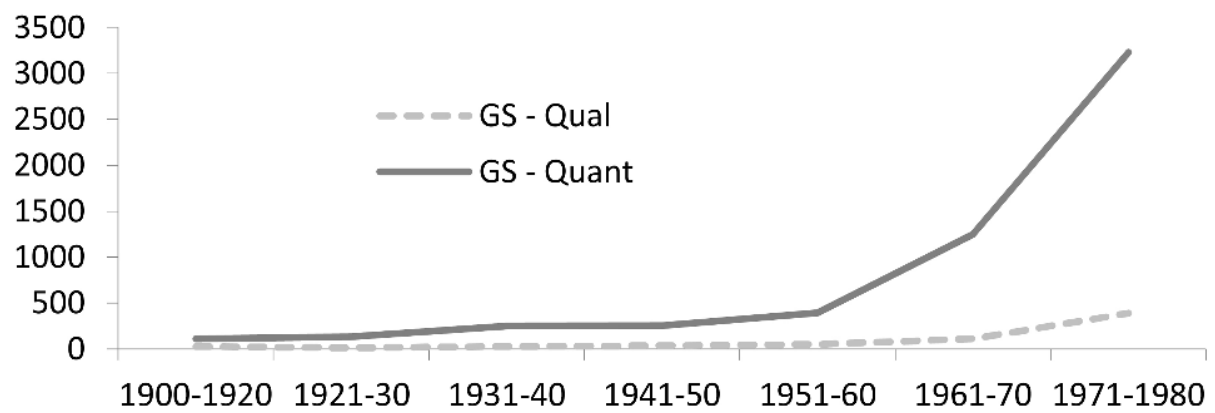

Gráfico 2

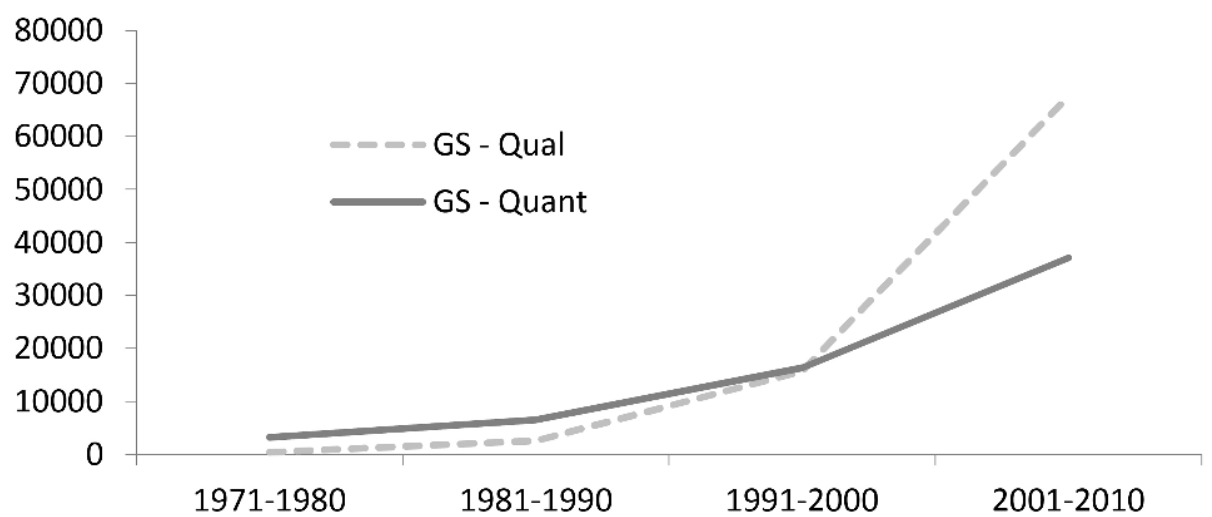

5 Como pode observar-se, a frequência de utilização destas expressões tem um ponto de viragem nos anos 90 quando as frequências de utilização das duas expressões se aproximam. Antes desta década, os documentos onde consta a expressão "métodos quantitativos" são sempre mais frequentes, enquanto na década seguinte se verifica o inverso: o número de documentos que contêm a expressão "métodos qualitativos" ultrapassa o daqueles onde se utiliza a expressão "métodos quantitativos".

6 Várias questões sobre a validade e a fiabilidade destes dados podem evidentemente ser levantadas. No entanto, se considerarmos que eles indiciam, apesar de tudo, alguma real diferença na utilização, em inglês ${ }^{3}$, das expressões "métodos qualitativos e "métodos quantitativos", é interessante realçar a supremacia dos "métodos qualitativos" na última década.

7 E, no entanto, uma outra pesquisa, utilizando agora a expressão "statistical methods" + social dá os seguintes resultados: o número de documentos em que se utiliza a expressão "métodos estatísticos" é sempre substancialmente mais frequente do que a de "métodos qualitativos" ou a de "métodos quantitativos".

8 Interessante também é verificar o acentuado crescimento relativo da utilização da expressão “métodos estatísticos”. Enquanto na década de 70, por exemplo, o número de publicações onde aparece esta expressão é aproximadamente 2,5 vezes mais elevada do 
que a de "métodos quantitativos", na primeira década deste século este valor cresce para 6.

Gráfico 3

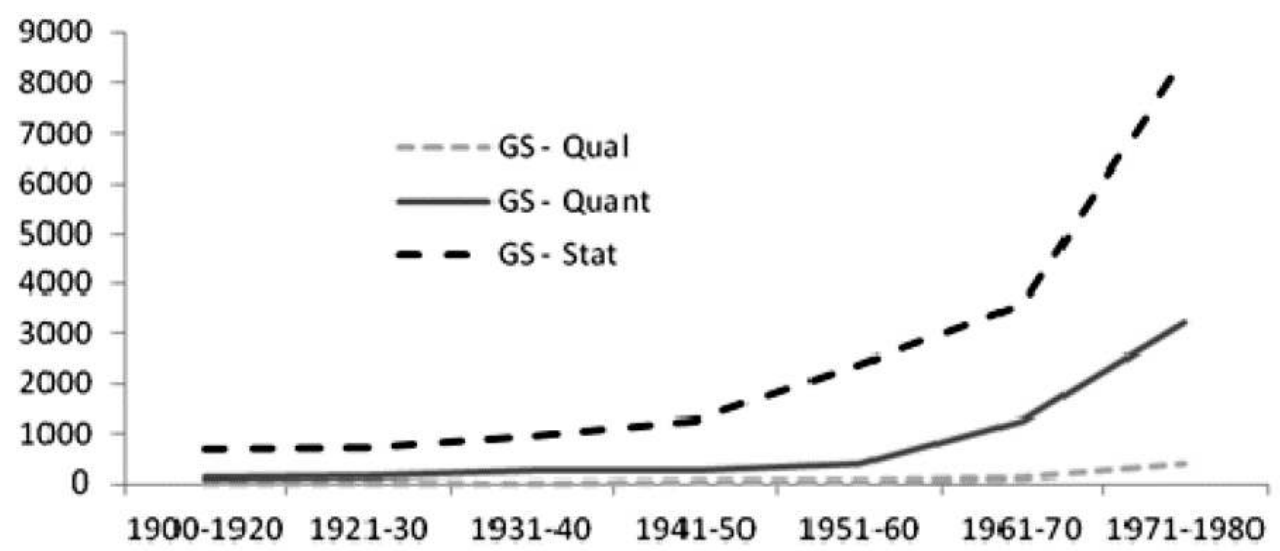

Gráfico 4

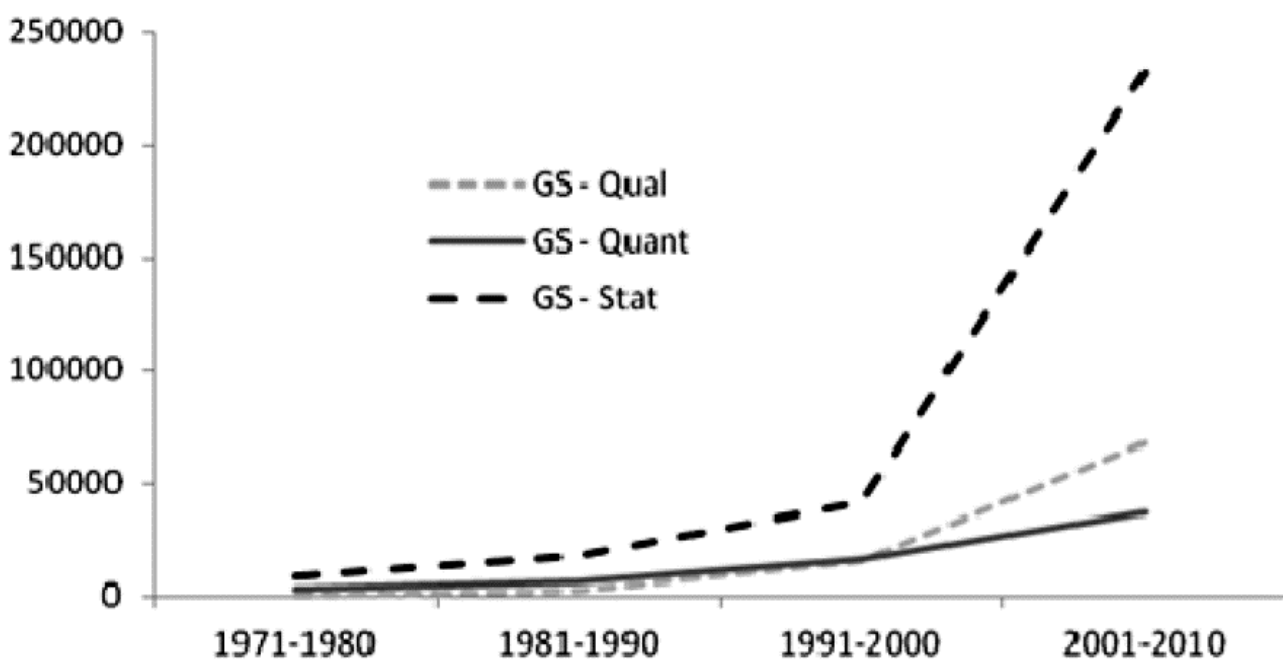

Esta incursão na história da utilização de expressões que caracterizam os métodos de pesquisa, meramente exploratória, é certo, levanta algumas questões interessantes que não podemos aqui aprofundar. Estes resultados poderiam ser confrontados, por exemplo, com outros dados da história das metodologias qualitativas já trabalhados. Vários autores ${ }^{4}$ propuseram já um faseamento da história dos métodos qualitativos na pesquisa empírica em ciências sociais: a sua importância e quase hegemonia na pesquisa social empírica no princípio do século passado com a Escola de Chicago (1915-30), a emergência dos estudos quantitativos e subordinação dos métodos qualitativos com a Escola de Colúmbia (1940-1950), a re-emergência dos métodos qualitativos, nos anos 60-70, estreitamente associados ao interacionismo e, a partir dos anos 80, a dissociação da expressão "métodos qualitativos" desta perspetiva teórica e epistemológica com a integração, nos "métodos qualitativos", de perspetivas distintas e com proveniências disciplinares diversas.

No entanto, a apresentação destes dados estatísticos num congresso sobre metodologias qualitativas não é uma simples provocação. Ela permite-nos desde já esclarecer uma 
primeira ambiguidade na terminologia utilizada. Por um lado, quando falamos de métodos quantitativos referimo-nos, de facto, quase sempre, aos métodos de pesquisa que assentam na estatística. Mais precisamente, que recorrem ao método das "variações concomitantes" como método que "atteint le rapport causal, non du dehors (...) mais par le dedans. (...), nous montre (deux faits sociaux) participant l'un de l'autre et d'une manière continue, du moins pour ce qui regarde leur quantité» (Durkheim, [1895] 1973: 129), tal como o apresenta Durkheim no capítulo sobre "as regras relativas à administração da prova". Ao contrário, a expressão "métodos qualitativos" remete para uma realidade bem menos definida e precisa: a do conjunto de métodos e técnicas que não recorrem à estatística nem aos "números" para descrever, analisar, explicar a realidade social.

Poderíamos aqui avançar uma hipótese quanto à terminologia utilizada no campo dos "qualitativistas". Seguindo a periodização de Poupart e outros (1983) e considerando os resultados dos quadros atrás apresentados, a expressão "métodos qualitativos" poderá ter-se estabilizado, a partir dos anos 80 e 90 , quando a utilização e reflexão sobre tais métodos se dissociou da perspetiva teórico-epistemológica interacionista. Até esta data encontraríamos assim, mais frequentemente, as expressões "estudos de caso" - como no trabalho pioneiro de Stouffer - ou "métodos etnográficos" - como nos textos dos interacionistas. Seria a inclusão, nas metodologias não quantitativas, de novas perspetivas, nomeadamente da história - com, por exemplo, a reflexão de Bertaux e Thompson ${ }^{5}$ sobre as histórias de vida e a história oral - e da linguística - com a crítica a uma análise de conteúdo que ignora o "discurso" e a sua função pragmática ${ }^{6}$, por exemplo, que levou à utilização de uma expressão menos diretamente associada ao método qualitativo "tradicional" - o trabalho de campo etnográfico.

A esta hipótese poderíamos associar uma outra que explicaria a supremacia do número de documentos "qualitativistas" relativamente aos "quantitativistas", a partir dos anos 90: a expressão métodos quantitativos é de facto utilizada, neste período, pelos autores que defendem as metodologias qualitativas e as opõem ao que designam por métodos quantitativos. Por sua vez, os defensores destes métodos pouco utilizam tal expressão, preferindo, provavelmente, expressões como fontes e métodos estatísticos, inquérito (survey) ou análise de dados.

13 Feito este primeiro esclarecimento sobre "de que falamos", é objetivo deste texto identificar, tão sistematicamente quanto possível, os termos do debate entre metodologias quantitativas e qualitativas tal como ele se traduz na prática da investigação empírica.

14 Tratarei assim sucessivamente as seguintes dimensões deste debate: recolha e análise de dados (1), discurso sobre a realidade observada e não observada (2) e contextos da prática da investigação empírica (3). Na sequência desta apresentação e na tentativa de corresponder ao título proposto para esta mesa, avançaremos algumas conclusões sobre a pertinência das "antigas querelas" e dos "debates recentes".

\section{Recolha e análise de dados ${ }^{7}$ na prática da investigação empírica}

Em geral, a oposição quantitativo-qualitativo remete diretamente para o problema de como produzir dados e que tipo de dados produzir. Sabendo que os diferentes modos de produção de dados estão associados à observação, à inquirição e à seleção de 
documentos/traços da vida social, uma decisão central para a construção de um desenho de pesquisa diz respeito à produção de dados numéricos ou de dados textuais. Assim, optaremos por uma observação in vivo com registo textual ou icónico de dados, por um lado, ou por uma observação, in vivo, com registo numérico da informação a partir de grelhas de observação estandardizadas, por outro ${ }^{8}$. Optaremos pela entrevista semidiretiva ou em profundidade, por um lado, ou pelo inquérito por questionário, por outro lado. Optaremos, enfim, por selecionar e recolher documentos registados na forma numérica (as estatísticas oficiais, por exemplo) ou na forma textual ou icónica (os romances ou os filmes, por exemplo). E estas opções traduzem-se certamente no tipo de análise de dados que visamos. Existe no entanto aqui, como sabemos, uma "pequena" assimetria: enquanto a produção de dados numéricos, numa pesquisa empírica, tem como corolário obrigatório a análise estatística de tais dados, já a produção de dados textuais pode implicar tanto a análise dos sentidos baseada na interpretação dos "textos", como a análise estatística, frequencial. Nesta última situação, a estandardização exigida pela análise estatística é feita a posteriori, sobre os próprios dados recolhidos (é o caso, por exemplo, da lexicometria) ou sobre sucedâneos destes dados trabalhados "qualitativamente" num primeiro momento (é o caso da análise categorial quantitativa, por exemplo).

Sabemos que não existe exclusividade de métodos "qualitativos" e "quantitativos" a este primeiro nível de construção do desenho da pesquisa. Numa mesma pesquisa empírica podemos produzir, manusear, analisar e interpretar dados quantitativos e dados qualitativos, com igual legitimidade científica e pelas melhores razões.

Esta coabitação de diferentes tipos de dados marca aliás, de forma exuberante, um dos primeiros trabalhos da sociologia empírica europeia, desenvolvido no início dos anos 30, em Marienthal, na Áustria, por uma equipa conduzida por P. Lazarsfeld (Jahoda, 1933) $)^{9}$.

18 Neste estudo designa-se por "sociografia" o método da pesquisa desenvolvida. Foram aqui recolhidos materiais tão diversos como:

1) Personal data about all 478 families of Marienthal village containing data about living conditions, family life, household establishment.; 2) Life history of 32 men and 30 women, whose previous life presented suitable material for comparison.; 3) 80 time images of the day.; 4) Reports from an industry commission of the Wiener Neustadt region from previous years.; 5) Essays of basic school children on the theme: "What I would like most of all," "What I would like to be," and "What I would like for Christmas."; 6) Competition essays of youth on the theme: "How do I envisage my future."; 7) 40 weekly family menus and reports about lunch packets of school children the day before and the day after the payment of social welfare.; 8) Reports about Christmas presents of 80 small children; 9) Statistical data about expenses of inhabitants in restaurants, at a hairdresser's, butcher's, horse butcher's, shoemaker's, tailor's or dressmaker's, and reports from political clubs and various societies and local organizations; ${ }^{10}$ ) Statistical data about library books from local library, subscriptions of various newspapers, club membership, election results, age structure, births, deaths and marriages of inhabitants and data about migration; 11) Household statistics from several households acquired by the chamber of commerce. (Jeřábek, 2005: 2-3.)

Segundo o próprio Lazarsfeld, "In Vienna we have attempted to represent the psychological aspect of unemployment by the methods of modern research. To this end we collected, over a period of three months, all the available material relating to the 
conditions of life among the inhabitants of Marienthal, a village of Lower Austria" (Lazarsfeld, 1933: 1).

É ainda Lazarsfeld que define as 4 regras do método seguido em Marienthal:

a) For every phenomenon under survey it is necessary to obtain objective observation as well as introspective reports; b) Case studies should be appropriately combined with statistical information; c) Information about present situation should be supplemented with information about previous phases of the development of the phenomenon under survey. d) Natural and experimental data should be combined: experimental data were understood as the use of questionnaires and selective surveys, natural data were acquired by "noninfluential (non-interfering) methods" - it was necessary to obtain the data from everyday life of people without any interference of the researcher. (Lazarsfeld, 1933.) 10

Lazarsfeld que, como se sabe, será um dos representantes da sociologia quantitativa americana, apresenta neste estrato as regras do "estudo de caso" onde se recolhem e analisam dados qualitativos (natural) e quantitativos (experimental), sobre o presente $\mathrm{e}$ o passado, na perspetiva da "combinação apropriada" da informação estatística e da informação sobre casos individuais para o conhecimento de uma comunidade marcada pelo fenómeno do desemprego, fenómeno que se pretende analisar.

\section{Discursos sobre a realidade observada e não observada}

Uma segunda dimensão do debate entre métodos quantitativos e qualitativos diz respeito aos discursos sobre a validade dos resultados alcançados com base na informação recolhida. Mais exatamente à validade "externa", isto é, à representatividade; o que levanta uma das questões que mais centralmente tem marcado este debate: a questão dos procedimentos de inferência.

É na tese de doutoramento de Stouffer, defendida na Universidade de Chicago em 1930, que alguns autores veem um indicador da emergência dos métodos quantitativos e subordinação dos métodos qualitativos que marcará as décadas de 40 e 50 . Como o título o indica, a tese é dedicada à comparação dos métodos de pesquisa sobre atitudes, distinguindo o autor o método estatístico do Case History Method. o autor coloca a questão da oposição entre estes dois métodos em termos da validade interna e externa dos resultados:

Summing up, we have on our hands two ifs. It may be said that an attitude test produces quickly and cheaply a set of indexes of enough people to make possible a study which holds constant a variety of factors associated with attitudes, but that the study may be worthless if the test does not measure what it purports to measure. On the other hand, the case method, so useful in suggesting preliminary hypotheses and in throwing light on the why of correlations quantitatively ascertained because it studies the individual's behavior and feelings in his own cultural setting, also may be dubious if competent investigators fail to agree in their sympathetic introspections. (Stouffer, 1930: 155.)

Stouffer conclui, ainda que prudentemente como o referem Poupart e outros, que um e outro método conduzem aos mesmos resultados, sendo que o método quantitativo é mais rápido e, aparentemente, mais fiável ${ }^{11}$. 


\section{Socorremo-nos aqui de um texto já clássico da perspetiva "qualitativista", o texto de} Becker publicado em 1996. Becker afirma ${ }^{13}$ :

I'm an intellectual descendant of Robert E. Park, the founder of what has come to be called the Chicago School of sociology. Park was a great advocate of what we now call ethnographic methods. But he was equally a proponent of quantitative methods, particularly ecological ones. I follow him in that, and to me the similarities between these methods are at least as, and probably more, important and relevant than the differences. (...) The two styles of work do place differing emphasis on the understanding of specific historical or ethnographic cases as opposed to general laws of social interaction. But the two styles also imply one another. Every analysis of a case rests, explicitly or implicitly, on some general laws, and every general law supposes that the investigation of particular cases would show that law at work. Despite the differing emphases, it all ends up with the same sort of understanding, doesn't it? (Becker, 1996: 1.)

That kind of ecumenicism clearly won't do, because the issue does not go away. To point to a familiar example, although educational researchers have done perfectly good research in the qualitative style for at least sixty years, they still hold periodic conferences and discussions, like this one, to discuss whether or not it's legitimate and, if it is, why it is. Surely there must be some real epistemological difference 
between the methods that accounts for this continuing inability to settle the question. (Becker, 1996: 1.)

A questão parece residir, pois, na irredutibilidade do conhecimento produzido no quadro das metodologias qualitativas àquele que é produzido através das análises estatísticas. O que tornaria irrelevante qualquer tentativa de articulação de procedimentos de inferência. Com efeito, Becker, nesta intervenção, recusa liminarmente tratar tal questão "epistemológica":

So: this paper will not be another sermon on how we ought to do science, and what we shouldn't be doing, and what evils will befall us if we do the forbidden things. Rather, it will talk about how ethnographers have produced credible, believable results, especially those results which have continued to command respect and belief. (Becker, 1996: 2.)

Assim, a um nível mais fundamental de articulação de procedimentos de inferência "quantitativos" e "qualitativos", tem sido do lado dos métodos quantitativos que têm surgido algumas propostas concretas.

É talvez de Ragin que vem um dos contributos mais importantes neste âmbito. O método designado Qualitative Comparative Analysis promove uma inversão na pesquisa quantitativa que, em vez da conventional variable-oriented analysis, passaria a case-oriented research (Ragin, 2005).

O objetivo de Ragin é ultrapassar as críticas à utilização da estatística clássica, traduzindo em modelo matemático, para efeitos de inferência, a lógica do estudo de caso. Utilizando a terminologia de Grossetti, a proposta de Ragin iria no sentido de compatibilizar as escalas de massa, de tempo e de contexto.

36 Ainda que a inovação da proposta de Ragin possa ter sido contestada ${ }^{14}$, ela permite relançar o debate sobre os fundamentos dos procedimentos de inferência em ciências sociais e recolocar a questão central: a da teoria que preside, na pesquisa empírica, à aplicação de uns e outros métodos.

What we are missing in social science methodology, it seems to me, is a theoretical grasp of how qualitative and quantitative methodologies go together (...) there is an (...) agenda that perhaps all of us could come to share. Acquiring the inferential insights that would let us see both types of methodology, (...) as genuinely distinct but legitimate and complementary - that, in my view, has not yet been done. (Achen, 2005: 31.)

37 Nesta perspetiva parece ser claro que não há lugar - nem será pertinente - apagar a oposição entre métodos quantitativos e qualitativos. Pelo contrário, como o referem, entre outros Achen e Ragin, ambos são genuinamente distintos e legítimos. O desafio está na construção teórica de objetos sociológicos que permita, além de um uso "paralelo" de dados qualitativos e quantitativos, articular diferentes procedimentos de inferência num mesmo desenho de pesquisa.

Esta é uma questão que tem sido abordada na ciência política, em particular na chamada política comparada, traduzindo-se na discussão sobre a definição dos "casos" e dos respetivos "contextos". Em sociologia parece haver matéria teórica suficiente, por exemplo a propósito de conceitos como o de organização, entre muitos outros, mas não tem sido verdadeiramente trabalhada, a nível metodológico, a definição de planos "intermédios" entre o "individual" e o "universal" que permitiriam a articulação de diferentes níveis e escalas de inferência ${ }^{15}$. 


\section{Contextos de práticas de pesquisa, relações entre saber e poder} forma, continuar a ser dominante no debate entre métodos qualitativos e quantitativos. Mesmo quando ultrapassada uma atitude que mais categoricamente nega a validade e pertinência dos métodos quantitativos ou dos métodos qualitativos, o paralelismo entre a oposição "quantitativo"/"qualitativo" e a oposição "dominante"/"dominado" parece ter sido incorporada pelas próprias comunidades científicas defensoras de um e outro método, desiguais em número e em visibilidade social. Esta realidade não será certamente alheia àquela que é indiciada pelas estatísticas apresentadas no início desta comunicação. Tal situação mereceria uma análise mais sistemática e, muito provavelmente, com resultados diversos nas diferentes comunidades científicas em diferentes países e também no interior de cada país. Sem tais resultados, atrevemo-nos no entanto a avançar a hipótese de que esta oposição pode explicar, em última instância, a relativa incomunicabilidade que caracteriza quantitativistas e qualitativistas.

Vale a pena recordar mais uma vez uma passagem do texto de Becker (1996) atrás citado.

Ordinarily, scholarly communities do not wander into each other's territory, and so do not have to answer to each other's criteria. Operating within the paradigm accepted in their community, social scientists do what their colleagues find acceptable, knowing that they will have to answer to their community for failures to adhere to those standards. When, however, two (at least two, maybe more) scholarly communities meet, as they did in this conference, the question arises as to whose language the discussions will be conducted in, and what standards will be invoked. It is my observation over the years that quantitative researchers always want to know what answers qualitative researchers have to their questions about validity and reliability and hypothesis testing. They do not discuss how they might answer the questions qualitative researchers raise about accuracy and precision and breadth. In other words, they want to assimilate what others do to their way of doing business and make those other ways answer their questions. They want the

Forum Sociológico, 24 | 2014 
discussion to go on in their language and the standards of qualitative work translated into the language they already use.

That desire - can I say insistence? - presumes a status differential: A can call B to account for not answering A's questions properly, but B has no such obligation to A. But this is a statement about social organization, not about epistemology, about power in hierarchical systems, not about logic. (Becker, 1996: 12.) criatividade científica nas ciências sociais. Assim, mais do que desvalorizar os debates, apagar a oposição ou entrincheirar-se num destes dois redutos, o que se traduz quase sempre na simplificação das argumentações e na naturalização da oposição entre métodos qualitativos e quantitativos, parece-me dever estar na ordem do dia a reflexão crítica sobre o que tem significado tal oposição e, sobretudo, sobre as formas de a transformar em mais-valia do pensamento crítico em ciências sociais.

Ao nível estritamente metodológico, a pluralidade de tipos de informação a produzir e analisar num mesmo desenho de pesquisa parece ser um dado adquirido, uma prática cada vez mais alargada e consensual. E, nesta perspetiva, a monografia sobre Marienthal já citada merece continuar a ser referência exemplar.

51 Já a caracterização ideal típica das práticas de investigação poderia ser desenvolvida avançando na definição dos princípios e das regras dos métodos em ciências sociais. $O$ que pode passar pela construção de formas de articulação entre as duas lógicas de investigação. A classificação que distingue os métodos "comparativo-extensivo", "de 
caso-intensivo" e a "comparação de casos" - numa tradução livre da tipologia de Ragin - é certamente um ponto de partida sólido para essa definição.

Ao nível epistemológico, incluindo aqui as questões das condições sociais da produção do conhecimento, assistimos hoje à consolidação de um único modelo legítimo de pesquisa sob formas avassaladoras quando comparadas com as que deram origem ao sobressalto dos métodos qualitativos nos anos 60: formas que vão do reconhecimento social da estatística ou até da pura aritmética, como único critério de validação do conhecimento, até à intervenção socio-organizacional, no campo científico, objetivamente castradora de modelos alternativos de pesquisa e de conhecimento.

Esta consolidação está associada na prática científica ao fenómeno, não abordado neste texto mas fundamental, da multiplicação de instrumentos de acesso e manuseamento da informação ${ }^{17}$, até agora desconhecidos. E, aparentemente, são as metodologias quantitativas que mais têm impulsionado e melhor têm aproveitado estes novos instrumentos: o que aparece de forma muito clara na supremacia absoluta das pesquisas baseadas em métodos quantitativos (estatísticos) como o indiciam os gráficos apresentados no início deste texto.

Nestas condições, os debates e as querelas tradicionais entre métodos qualitativos e quantitativos aparecem como um lugar crucial da nossa memória a partir do qual é possível e desejável a construção de um novo pensamento crítico sobre a prática da pesquisa empírica em ciências sociais.

\section{BIBLIOGRAFIA}

ACHEN, C. H. (2005), "Two Cheers for Charles Ragin”, Studies in Comparative International Development, Spring, Vol. 40, No. 1, pp. 27-32. Disponível em http://polisci.berkeley.edu/people/ faculty/CollierD/4b\%20-\%20Comment\%20by\%

20Achen\%20-\%20\%202005.pdf.

BECKER, H. S. (1996), "The Epistemology of Qualitative Research”, in R. Jessor, A. Colby e R. Shweder (eds.), Essays on Ethnography and Human Development. Context and Meaning in Social Inquiry, Chicago, University of Chicago Press, pp. 53-71. Disponível em http://www.sfu.ca/ palys/BeckerEpistemologyOfQualitativeResearch.pdf.

BECKER, H. S. (1999), “The Chicago School, So-Called”, Qualitative Sociology, 22 (1), pp. 3-12.

BECKER, H. S. e C. Ragin (1989), "How the Microcomputer is Changing Our Analytic Habits", in G. Blank, J. L. McCartney e E. Brent (eds.), New Technology in Sociology: Practical Applications in Research and Work, New Brunswick, Transaction Publishers, 1989, pp. 47-56.

BERTAUX, D. (ed.) (1981), Biography and Society: the Life History Approach in the Social Sciences, Beverly Hills, Sage.

BERTAUX, D. e P. Thompson (eds.) (1993), Between Generations: Family Models, Myths, and Memories, International Yearbook of Oral History and Life Stories, vol. II, Oxford, Oxford University Press. 
BERTAUX, D. e C. Delcroix (2000), “Case histories of Families and social processes. Enriching sociology", in P. Chamberlayne, J. Bornat e T. Wengraf (eds.), The Turn to Biographical Methods in Social Science. Comparative issues and examples, London, Routledge.

DURKHEIM, E. ([1895] 1973), Les règles de la méthode sociologique, Paris, PUF.

GOFFMAN, E. (1982), “The interaction order”, Presidential Address, American Sociological Association, disponível em: http://www2.asanet.org/governance/PresidentialAddress1982.pdf. GROSSETTI, M. (2006), “Trois échelles d'action et d'analyse”, L’Année Sociologique, 56 (2), pp. 285-307.

JAHODA, M., P. F. Lazarsfeld e H. Zeisel (1933), Die Arbeitslosen von Marienthal, Ein soziographischer Versuch mit einem Anhang zur Geschichte der Soziographie, Leipzig, S. Hirzel Verlag (Os desempregados em Marienthal. Ensaio sociográfico com um anexo sobre a história da sociografia). Tradução em inglês: Marienthal. The Study of an Unemployed Community (1971), Londres, Tavistock; tradução em francês: Les Chômeurs de Marienthal (1981), Paris, Éditions de Minuit.

JEŘÁBEK, H. (2005), Three examples of cooperation between qualitative and analytical research. (Lazarsfeld's research workshop.), Institute of sociological studies, Faculty of Social Sciences, Charles University, disponível em http://cvvm.soc.cas.cz/en/2005-2/three-examples-of-cooperationbetween-qualitative-and-analytical-research-lazarsfeld-s-research-workshop.

LAZARSFELD, P. (1933), “An unemployed village”, Character and Personality. An International Quarterly of Psychodiagnostics and Allied Studies, September, 1932 - June, 33, 1, 147-151, disponível em http://www.sozpsy.uni-hannover.de/marienthal/archiv/archiv211.html.

MAINGUENEAU, D. (1976), Initiation aux méthodes d'analyse du discours, Paris, Hachette.

MAINGUENEAU, D. (1987), Nouvelles tendances en analyse du discours, Paris, Hachette.

MAINGUENEAU, D. (1991), L'analyse du discours, introduction aux lectures de l'archive, Paris, Hachette.

MATOS, M., I. Duarte et al. (2012), “O Risco educativo no ensino básico”, in AAVV, Promoção do Sucesso educativo, Projectos de pesquisa, Lisboa, Fundação Calouste Gulbenkian.

MILLS, C. W. (1959), The Sociological Imagination, Oxford, Oxford University Press.

POUPART, J. et al. (eds.) (1997), La recherche qualitative. Enjeux épistémologiques et méthodologiques, Montréal, Gaëtan Morin; tradução brasileira (2008), Editorial Vozes, Rio de Janeiro.

POUPART, J., P. Rains e A. P. Pires (1983), «Les méthodes qualitatives et la sociologie américaine», Déviance et société, Vol. 7 (1), pp. 63-91.

RAGIN, C., (2005) From Fuzzy Sets to Crisp Truth Tables, Department of Sociology, University of Arizona, April 2005, disponível em http://www.compasss.org/wpseries/Ragin2004.pdf.

STOUFFER, S. A. (1930), An Experimental Comparison of Statistical and Case History Methods of Attitude Research, Doctoral Dissertation, University of Chicago, Disponível em http://www.brocku.ca/ MeadProject/Stouffer/1930/Stouffer_1930_toc.html.

THOMPSON, P. (1985), The voice of the past: oral history, Oxford, Oxford University Press. 


\section{NOTAS}

1. Comunicação apresentada no V Congresso Ibero-Americano de Pesquisa Qualitativa em Saúde - Circulação de Saberes e Desafios em Saúde, realizado em Lisboa entre 11 e 13 de Outubro de 2012.

2. Pelo menos se considerarmos a tese de doutoramento de Stouffer (1930) como um primeiro momento de "institucionalização" desta oposição.

3. Ensaiamos o mesmo exercício com as expressões em português, que apenas nos revelou o já esperado: o número de referências de documentos em português, encontrados através do Google Scholar, é demasiado reduzido, só tendo alguma expressão estatística nos anos 2000. Ainda assim os "métodos quantitativos" são aqui sempre mais frequentes do que os "métodos qualitativos". Refira-se ainda que as primeiras referências a documentos que incluem a expressão "métodos quantitativos" aparecem na década de 60 (8 referências), enquanto a expressão "métodos qualitativos" aparece na década de 70 (4 referências). Os outros valores são, para os "métodos quantitativos, 42 na década de 70, 78 na de 80, 623 na de 90 e 8940 depois de 2000. Para os métodos qualitativos os valores são: 10 na década de 80, 233 na de 90 e 6720 depois de 2000 . Se a possibilidade e a decisão de disponibilizar na rede os documentos que vão sendo produzidos nos vários países do mundo colocam um problema de fiabilidade deste tipo de dados, cremos que este problema se agudiza no caso português, mesmo incluindo a produção científica brasileira.

4. Ver os trabalhos do Groupe de recherche interdisciplinaire sur les méthodes qualitatives: por exemplo o texto de Poupart et al. (eds.) (1997) assim como um texto anterior de Poupart, Rains e Pires (1983).

5. Ver Bertaux (1981), Thompson (1985), Bertaux e Thompson (1993), Bertaux e Delcroix (2000).

6. Ver, por exemplo, os textos de Maingueneau (1976, 1987 e 1991).

7. Por simplificação utilizamos a palavra "dado", não sendo nunca de mais parafrasear Bourdieu: os dados não são dados...

8. Não refiro aqui a observação in vitro, no laboratório, frequentemente usada em psicologia social. No entanto parece certo que este tipo de observação assenta principalmente na quantificação.

9. Texto traduzido em inglês só em 1971 e em francês, com prefácio de P. Bourdieu, em 1981.

10. Segundo a tradução inglesa da 2. edição em 1974. Citado por Jeřábek (2005: 2).

11. Recordamos aqui a observação de Becker (1999) sobre a heterogeneidade da Escola de Chicago, onde os defensores dos métodos quantitativos estariam presentes desde a primeira hora. Entre estes, Becker refere Stouffer.

12. Retiro estas noções de escalas de inferência do texto de Grossetti (2006).

13. As citações deste texto de Becker são retiradas do texto publicado online pela Simon Fraser University, Canada, disponível em http://www.sfu.ca/ palys/BeckerEpistemologyOfQualitativeResearch.pdf.

14. Ver Achen (2005).

15. Tentámos explorar as potencialidades da definição metodológica destes planos intermédios numa pesquisa sobre a escola em Portugal (Matos, Duarte et al., 2012).

16. Uma formulação paradigmática desta perspetiva é, por exemplo, a de Goffman na conferência da ASA, em 1982: "If one must have warrant addressed to social needs, let it be for unsponsored analysis of the social arrangements enjoyed by those with institutional authority - priests, psychiatrists, school teachers, police, generals, government leaders, parents, males, whites, nationals, media operators, and all the other well-placed persons who are in a position to give official imprint to versions of reality."

17. Veja-se a este propósito um texto pioneiro de Becker e Ragin (1989) sobre as consequências do uso dos computadores pessoais. 


\section{RESUMOS}

Depois de quase um século de debates vale a pena perguntar de que falamos hoje quando opomos os métodos qualitativos aos métodos quantitativos. No texto esboça-se uma análise das diferentes dimensões desta oposição entre "métodos". Entendendo aqui o método como "lógica de investigação", defende-se a necessidade de desenvolver formas de articulação entre as duas lógicas, nomeadamente no que diz respeito ao problema da inferência. Este desenvolvimento implica um trabalho não só ao nível metodológico e técnico mas também e sobretudo ao nível da construção teórica de "planos intermédios" de objetos de pesquisa.

After almost one century of discussions it is worth asking what we nowadays are talking about when we set qualitative against quantitative methods. The paper outlines an analysis of the different dimensions of this opposition between "methods". Method is here taken as "research logic", and we argue for the need of developing forms of linkage between the two logics, in particular regarding the problem of inference. This development requires us to work not only on the methodological and technical level, but above all on the level of the theoretical construction of "intermediate levels" of research objects.

\section{ÍNDICE}

Keywords: qualitative methods, quantitative methods, linkages between methods, inference Palavras-chave: método qualitativo, método quantitativo, articulação entre métodos

\section{AUTOR}

\section{MADALENA MATOS}

Iscte-IUL - Portugal, Departamento de Sociologia e Dinâmia-CET (madalena.matos@iscte.pt) 